\title{
LANGUAGES AND LANGUAGE VARIETIES: COMPARATIVE RESEARCH ON THE LINGUISTIC ATTITUDES IN FOUR BILINGUAL MINORITY COMMUNITIES IN HUNGARY
}

\author{
Anna Borbely \\ Hungarian Academy of Sciences
}

\begin{abstract}
A central issue of this paper is to study the patterns in variation of attitudes toward minority language varieties in four minority communities from Hungary: German, Slovak, Serb and Romanian. This study takes part from the research which focuses on how to obtain significant information about the mechanism of the language shift process concerning autochthonous minorities in Hungary. The results demonstrate that in the course of language shift communities at an advanced stage of language shift have less positive attitudes toward their minority languages than individuals from communities where language shift is in a less advanced stage. In Hungarian minority groups speakers' attitudes toward minority language varieties (dialect vs. standard) are the symptoms of language shift.
\end{abstract}

Keywords: language shift, language attitudes, dialects vs. standard, comparative research

\section{The problem}

A central issue of this paper is to study the patterns in variation of attitudes toward minority language varieties in four minority communities. This study takes part from the research which focuses on how to obtain significant information about the mechanism of the language shift process concerning autochthonous minorities in Hungary (see e.g. Kontra 1997, Borbély 2001, Bartha and Borbély 2006).

Attitude is an interdisciplinary term, bridging psychology and sociology, but it has become also a term of linguistics, in particular in psycholinguistics and sociolinguistics. Attitudes play a powerful role in determining one's behavior (Lambert and Lambert 1973), and it may also be viewed as reflections of behavior (Brudner and Douglas 1979). The main factors which influence language atti- 
tudes are historical, social and political changes, for example changes in language policy (cf. Woolard and Gahng 1990). For these reasons the attitudes of the speaker, who is a member of a minority community being in language shift process, may be regarded as an important factor in the description of his/her bilingualism. In addition, it must be clarified that the process of language shift is not a linear change. The real and apparent time analyses realized in 1990 and in 2000, in the Hungarian-Romanian minority community regarding the changes in bilingual language choice, revealed that middle-aged (40-58-year-old) subjects were less influenced by general social/political changes than younger ones (18-39-yearold). Both groups were equally influenced only by local social community changes (Borbély 2005). A further evidence of non-linear change of language shift process can be provided by studying the variation of attitudes toward minority language varieties (dialect vs. standard) in the same country focusing on cross-community differences. In this paper, based on comparative data collected from four minority groups in Hungary, I would like to provide evidence that in the studied minority communities the patterns of attitudes toward varieties of minority languages (dialect vs. standard) differ from each others, and this variation could be an important symptom or factor in the course of language shift reflecting different phases and/or dynamics.

\section{Short historic background of the Hungarian minorities ${ }^{1}$}

From the Hungarian conquest (895) throughout the entire history of Hungary the presence of minorities are manifested, and following many long centuries in the first part of the 20th only more than the half $(51,4 \%)$ of the population had Hungarian as mother tongue. The assimilation of minorities in the Hungarian mass of the population is well-known. In Hungary there is an extended, ironic proverbial description for own roots fitted personally, as the following example show us: "Both my grandmoth-

\footnotetext{
The Act LXXVII of 1993 on the Rights of National and Ethnic Minorities defines the Bulgarian, Gypsy (Roma and Boyash), Greek, Croatian, Polish, German, Armenian, Romanian, Ruthenian, Serb, Slovak, Slovene and Ukrainian ethnic groups as national or ethnic minorities native to Hungary.
} 
ers are Bunjevci, my grandfather by father side is Swabian and by mother side is Polish. Therefore I am insightful clearly Hungarian" (Lindner and Horváth 2007: 114). Until and in the 19th century the relationship of Hungarians and most minorities living in Hungary could be characterized predominantly with a coexistence living side by side, due to the social circumstances characteristic to this time period. The linguistic consequence of this circumstance was that the majority of the members of the minority groups were monolingual, speaking only their own minority languages. In the 20th century, due to the historical, political and economical changes, the relationship of Hungarians and the minorities living in Hungary could be characterized more and more with a coexistence living together. As a result, the members of the minority groups began to become bilinguals (Borbély 2007). However, today the bilingualism of minority groups in Hungary is not a stable but a temporary one (see Fishman 1968, Gal 1979: 2 ), since the functions of the language use of the own minority language and the majority language do not set apart from each other. The 20th century is full of serious historical events, which had influence on the change of the minorities' community life. These historical events, totally (or partially) ignoring human and minority rights, generated profoundly the significant decrease of the size, the assimilation process and the language shift of the indigenous minorities living in Hungary.

In Hungary members of minority communities still speaking their mother tongue, speak a local variety of their minority language. Very few of them, mainly intellectuals, speak a variety close to the standard, in addition to their local dialect. The standard variety of minority languages spoken in Hungary are contact varieties, and are learned varieties developed by systematic (or accidental, depending on the proficiency in standard variety of the speaker) replacement of dialectal elements of the local variety (the mother tongue) with the corresponding elements of the standard. A small part of the younger generations of the communities, who started to learn minority languages at school, speak only the standard variety of the minority languages. The dialects of minority languages are used mostly in conversations within family, between friends, or neighbors, at meetings with minority in-group relatives. At public domains the right of minority language use is exhausted in putting name boards of minority settlements and local offices. National official personal documents are always monolingual Hungarian, and 
today $^{2}$ the minorities have the opportunities to choose minority first name for their children.

\section{The data}

The present research is based on the data of a national survey on ongoing linguistic and sociolinguistic changes within six linguistic minorities in Hungary. The main aim in the framework of the project Dimensions of being linguistically different - Possibilities for preserving minority languages (2001-2004) is to describe the forms of language shift and language maintenance in minority communities; forms of social conduct bilingualism, minority attitudes and prejudices in the communities studied in Hungary. The 421 subjects were selected (by age, sex and education) from the following speech communities (and towns or villages): Boyash (Mánfa, Alsószentmárton), German (Tarján), Roma (Mezőtür), Romanian (Kétegyháza), Slovak (Tótkomlós) and Serbian (Pomáz) (see Bartha 2007, Borbély 2007, Erb 2007, Pálmainé Orsós 2007, Uhrin 2007).

In the study of attitudes toward varieties of minority languages (dialect vs. standard), the dialect variety is represented by the local variety spoken in the towns or villages where subjects are living (e.g. German spoken in Tarján; Slovak spoken in Tótkomlós), and the standard variety are represented by languages spoken in homeland/mother-tongue land (e.g. Germany, Slovakia). In the case of Boyash and Roma communities there are no such countries, so we omitted both communities from this resent study. For this reason data have been examined from the following four minority communities from Hungary: German, Slovak, Serb and Romanian.

The language attitudes toward the two varieties of minority languages are examined with direct questions. The questionnaires were administered orally by field workers, who were members in the studied communities and speak the local variety of the community languages. The questionnaires had been filled in by field worker

2 In spite of the 12.§ (1) section of the Minority Act (1993/LXXVII) this is allowed only from 2000. After this year a collection of personal names of 12 minorities living in Hungary was published (S. Dávid, 2004), and a separate collection of German names in 2004. 
and the data collection was also recorded by cassette player. The questionnaires contain totally 142 questions. From these it will be examined four language attitudes questions (Q65-Q103). The following questions (and the possible three answers: A1, A2, A3) were borrowed - and translated in English - from the questionnaire used in the Hungarian-Romanian community in Kétegyháza interviewed in local Romanian language variety:

(Q65) Which language do you consider more beautiful: the Romanian spoken in Kétegyháza or the one spoken in Romania? (A1) the one in Kétegyháza (A2) both (A3) the one in Romania

(Q66) Which language do you consider more useful: the Romanian spoken in Kétegyháza or the one spoken in Romania? (A1) the one in Kétegyháza (A2) both (A3) the one in Romania

(Q67) Which language do you consider more difficult: the Romanian spoken in Kétegyháza or the one spoken in Romania? (A1) the one in Kétegyháza (A2) both (A3) the one in Romania

(Q68) Which language do you like: the Romanian spoken in Kétegyháza or the one spoken in Romania?

(A1) the one in Kétegyháza (A2) both (A3) the one in Romania

The answers gathered by questionnaires from 281 subjects were analyzed with quantitative methods: descriptive statistics and inferential statistics (e.g. Tukey-Kramer method, see Vargha 2007) with ROPstat (www.ropstat.com) statistical package. In the next section the most frequent answers (in percentage) will be presented for each question and each community, and also the significant cross-communities differences among them.

\section{Results: attitudes toward minority language varieties}

\subsection{Emotional attitude (Which language [variety] do you like? Q68)}

According to the data regarding this question in the studied four minority communities the most frequent response of the subjects showed that subjects like more the dialect (local variety of the minority language, see A1 in Table 1) than the standard vari- 
ety (spoken e.g. in Slovakia, Romania). Germans gave the highest percentage (74.3\%), the smallest Romanians (50.7\%), and Slovaks' $(61.4 \%)$ and Serbs' $(67.1 \%)$ percentages were between. The pairwise comparison showed significant differences between Romanians and the other three communities. Germans, Serbs and Slovaks like significantly $(\mathrm{p}<.01)$ more the dialect variety of their minority language than Romanians.

Table 1. The most frequent answers for each question in each community, and cross-communities differences. ${ }^{3}$

\begin{tabular}{|c|c|c|c|c|c|c|c|c|c|c|c|c|}
\hline \multirow[b]{3}{*}{ Attitudes } & \multicolumn{12}{|c|}{ Minority languages/answers (A) } \\
\hline & \multicolumn{3}{|c|}{ Serb } & \multicolumn{3}{|c|}{ Slovak } & \multicolumn{3}{|c|}{ Romanian } & \multicolumn{3}{|c|}{ German } \\
\hline & A1 & A2 & $\mathbf{A 3}$ & A1 & $\mathbf{A 2}$ & A3 & A1 & $\mathbf{A 2}$ & $\mathbf{A 3}$ & A1 & A2 & $\mathbf{A 3}$ \\
\hline $\begin{array}{l}\text { Like } \\
\text { (emotional; } \\
\text { Q68) }\end{array}$ & 67.1 & & & 61.4 & & & $\begin{array}{l}\mathbf{5 0 . 7} \\
* * *\end{array}$ & & & 74.3 & & \\
\hline $\begin{array}{l}\text { Beautiful } \\
\text { (esthetic; } \\
\text { Q65) }\end{array}$ & & 47.1 & & & & $\begin{array}{l}68.1 \\
* *\end{array}$ & & & $\begin{array}{l}47.9 \\
*\end{array}$ & 54.3 & & \\
\hline $\begin{array}{l}\text { Useful } \\
\text { (functional; } \\
\text { Q66) }\end{array}$ & & & 45.7 & & & 43.1 & & & $\begin{array}{l}62.9 \\
*\end{array}$ & & & $\begin{array}{l}81.4 \\
* *\end{array}$ \\
\hline $\begin{array}{l}\text { Difficult } \\
\text { (competence; } \\
\text { Q67) }\end{array}$ & & & 71.4 & & & 79.4 & & & $\begin{array}{l}\mathbf{8 1 . 4} \\
+\quad\end{array}$ & & & 58.6 \\
\hline
\end{tabular}

\subsection{Esthetic attitude (Which language [variety] do you consider more beautiful? Q65)}

The most diverse answers had been obtained for the esthetic attitude. Most of Germans said that dialect is more beautiful than standard (54.3\%) (see A1 in Table 1). Most of Serbs (47.1\%) assumed in the same way both are beautiful (see A2 in Table 1). Most of Slovak (68.1\%) and most of Romanian (47.9\%) respondents said standard is more beautiful than dialect (see A3 in Table 1). Comparing the minority communities' answers to each other,

3 Symbols in the table: A1 = local variety (dialect) of the minority language; A2 = both: local variety of the minority language and standard variety of the minority language; $\mathrm{A} 3=$ standard variety of the minority language; $+=\mathrm{p}<.10$; $*=\mathrm{p}<.05 ; * *=\mathrm{p}<.01$. 
statistical results showed significant differences among them. Slovak $(\mathrm{p}<.01)$ and Romanian $(\mathrm{p}<.05)$ answers differ significantly from the answers of German and Serb subjects.

\subsection{Functional attitude (Which language [vari- ety] do you consider more useful? Q66)}

Looking the practical/functional view of minority language varieties in the four studied communities the highest percentages reveal that standard variety is more useful than dialect variety (see A3 in Table 1). The highest percentage is presented in the German community $(81.4 \%)$, the smallest in the Slovak community $(43.1 \%)$, and Serbs' percentage $(45.7 \%)$ and Romanians' percentage $(62.9 \%)$ are in between. Tukey-Kramer method shows significant differences among these four communities. Romanians $(\mathrm{p}<.05)$ and Germans $(\mathrm{p}<.01)$ considered more useful the standard variety - in comparison with dialect variety - than the Serb and the Slovak respondents.

\subsection{Competence attitude (Which language [variety] do you consider more difficult? Q67)}

In these four communities the highest percentages of the answers to this question reveal that standard variety is more difficult than dialect variety (see A3 in Table 1). Subjects who gave this response were in highest percentages Romanians (81.4\%), the other community results are: Slovaks (79.4\%), Serbs (71.4\%), and Germans $(58.6 \%)$. Comparing the four community results with each other, there is a tendency difference $(p<.1)$ : the Romanians' answers are higher than the answers obtained in the other three communities.

\section{Patterns of attitudes toward minority language varieties}

Calculating the mean of percentages of the three possible answers (A1 = dialect, $\mathrm{A} 2$ = both, $\mathrm{A} 3$ = standard) for the four 
questions (Q65-Q103) in the four communities we can differentiate three different patterns of attitudes.

\subsection{The respondents' relation to the both varieties}

The Serb community is related more to the both varieties, as the respondents' answers to the four questions are separated nearly in the same three parts (see Figure 1).

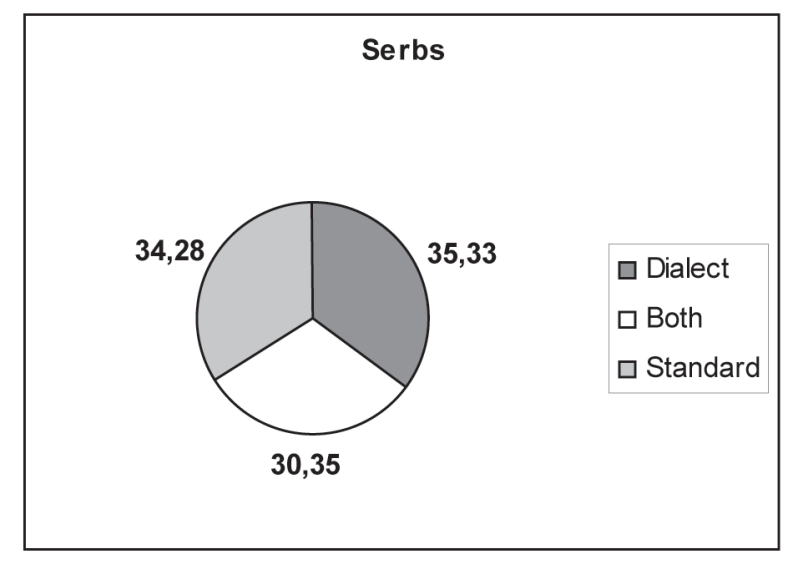

Figure 1.

\subsection{The respondents' relation to the standard variety}

In Slovak and Romanian communities the answers are reasonably similar: in both communities the respondents' answers are related mostly to the standard variety of minority languages, and the less to the both varieties (see Figure 2 and Figure 3). 


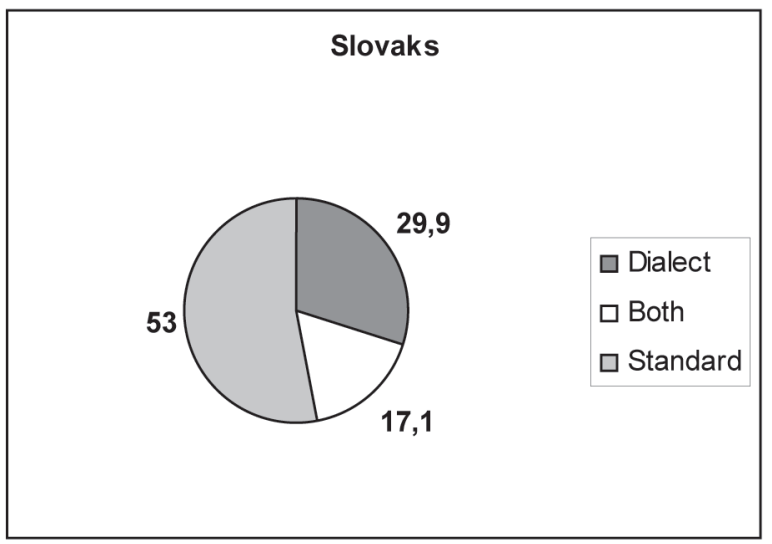

Figure 2.

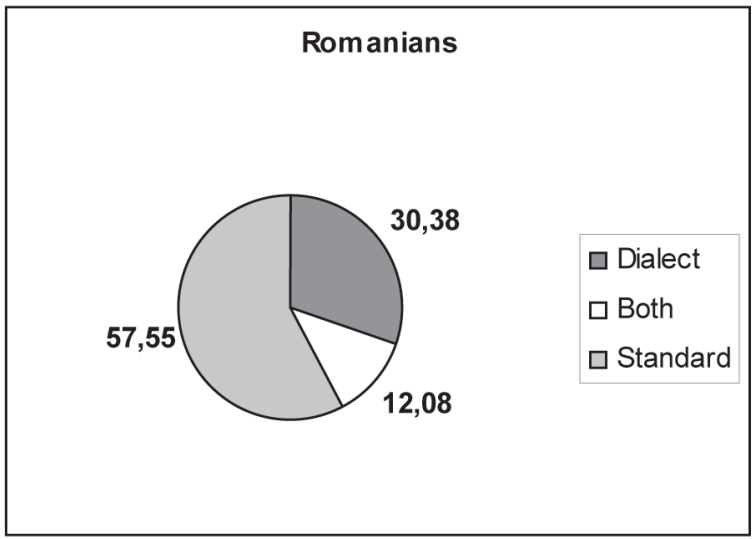

Figure 3.

\subsection{The respondents' relation to the dialect variety and to the standard variety}

In the German community the answers are often related to the dialect, or to the standard, but rarely to both varieties (see Figure 4).

From the above discussion, it may possibly be remarkable, to analyze the correlations of the language attitudes toward minor- 
ity language varieties with the choice of minority languages. The obtained three different pattern types of attitudes toward the varieties of minority languages can possibly be reflected in different types of choice of minority languages. The following section describes these attitude patterns toward minority language varieties, detected in these four communities, how they correlate with the choice of minority languages.

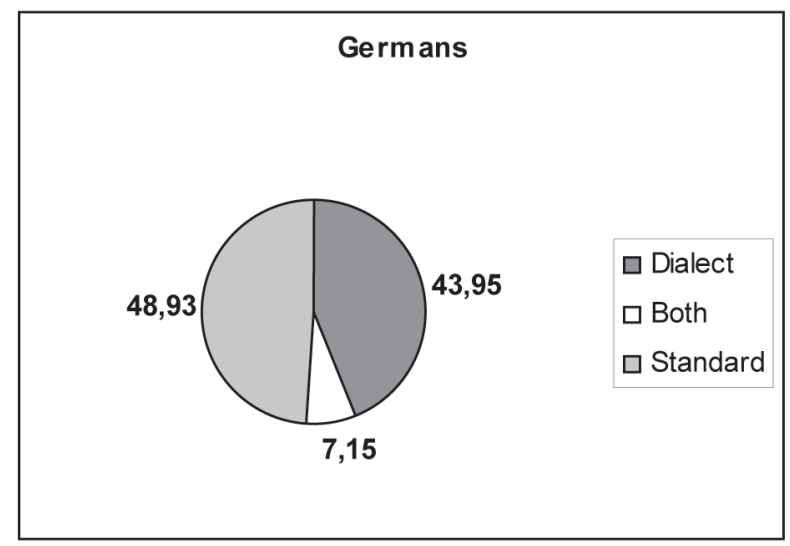

\section{Figure 4}

\section{Minority language attitudes and the choice of minority languages}

In the course of the data collection we examined also the choice of minority languages and the Hungarian. From the questionnaire it will be analyzed the answers concerning the bilingual language choice in 22 questions (22 situations). These questions were formulated e.g. as follows: What language do you use with your mother/friend/child/etc.? The possible answers, a five-point scale covers a broad range of answers: $1=$ always minority language; 2 = mostly minority language; 3 = both language similarly; $4=$ mostly Hungarian language; 5 = always Hungarian language. We calculated mean percentages of the answers (I use) $1=$ always minority language of these 22 situations in four Hungarian minority communities. Results demonstrate that minority language is used most frequently in Serb community (50\%), and in German commu- 
nity was said to be used the least (14\%). Slovaks' (28\%) and Romanians' $(28 \%)$ percentages were between (see Figure 5).

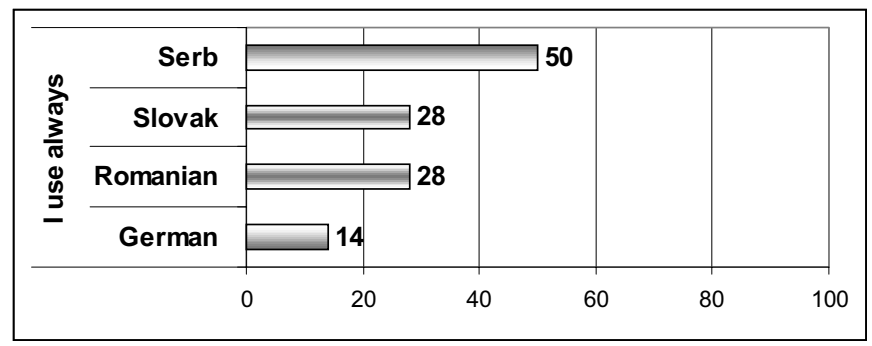

Figure 5. The choice of minority languages: mean of percentages in 22 situations (see Borbély 2006).

Comparing the three attitude patterns (see 5.1, 5.2., 5.3.) of four Hungarian minority communities with the choice of minority languages in 22 situations we discovered the following correlations between attitudes and the choice of minority languages (see Figure 6).

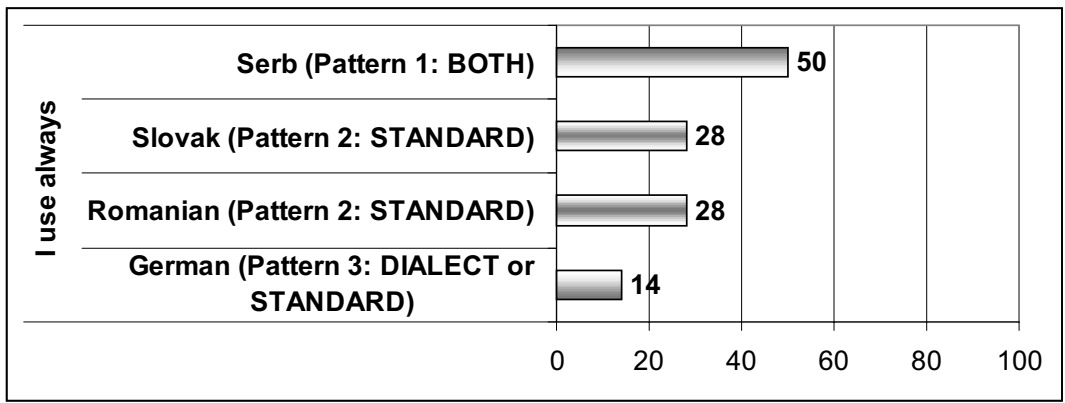

Figure 6. Comparing the 3 attitude pattern types with the choice of minority languages.

- In the Hungarian-Serb community - where the language attitudes are related the most to the both varieties of minority language - the minority language (Serbian) is chosen more frequently than in the other three communities.

- In the Hungarian-Slovak and Hungarian-Romanian communities - where the language attitudes are related to the 
standard variety, the minority languages are chosen less frequently than in Serb community.

- In the Hungarian-German community - where the language attitudes are related less to the both varieties - the minority language (German) is chosen less frequently than in the other three communities.

\section{Conclusions}

Cross-community differences of linguistic attitudes and minority language choice are taken into account, even in the case of the seemingly identical sociolinguistic settings (e.g. political, social, minority language policy background) in Hungary. The presented three patterns of linguistic attitudes provide proofs that the process of language shift is a non-linear change (see also Borbély 2005). Even in the same country cross-community differences are realized, that reflect: in minority community where the members are related to the both varieties of the minority language the process of language shift is in its less advanced phase than in the community where the members have positive attitudes to the standard variety. The most advanced phase of language shift is shown in the community where the members have the highest positive attitude either to the dialect or to the standard separately but not to the both varieties together. In Hungarian minority communities the maintenance of the minority languages will be successful only if the members will have positive attitudes and relations not only to the dialect or to the standard varieties consecutively, but to the both varieties simultaneously (as it is in the Serb community) (see Table 2).

Table 2. Language attitudes and phases in language shift in four Hungarian minority groups.

\begin{tabular}{|c|c|c|c|}
\hline Minority groups & Serbs & $\begin{array}{l}\text { Slovaks, } \\
\text { Romanians }\end{array}$ & Germans \\
\hline $\begin{array}{l}\text { POSITIVE } \\
\text { ATTITUDES TOWARD } \\
\text { MINORITY } \\
\text { LANGUAGE } \\
\text { VARIETIES }\end{array}$ & $\begin{array}{l}\text { TO BOTH } \\
\text { (DIALECT AND } \\
\text { STANDARD) }\end{array}$ & TO STANDARD & $\begin{array}{l}\text { TO DIALECT OR } \\
\text { TO STANDARD }\end{array}$ \\
\hline $\begin{array}{l}\text { PHASES IN } \\
\text { LANGUAGE SHIFT } \\
\text { (THE CHOICE OF } \\
\text { LANGUAGES) }\end{array}$ & $\begin{array}{l}\text { LESS } \\
\text { ADVANCED } \\
\text { PHASE }\end{array}$ & $\begin{array}{l}\text { ADVANCED } \\
\text { PHASE }\end{array}$ & $\begin{array}{l}\text { MOST } \\
\text { ADVANCED }\end{array}$ \\
\hline
\end{tabular}


These results demonstrate that in the course of language shift communities at an advanced stage of language shift have less positive attitudes toward their minority languages than individuals from communities where language shift is in a less advanced stage. In Hungarian minority groups speakers' attitudes toward minority language varieties (dialect vs. standard) are the symptoms of language shift as e.g. the choice of minority languages are in the life of minority communities.

\section{Acknowledgements}

The paper is based on the data of the collective research "Dimensions of linguistic otherness: Prospects of minority language maintenance in Hungary" (the National Research and Development Programme 5/126/2001), coordinator of consortium: Csilla Bartha, coordinator of research topic: Anna Borbély, and EACEA 2008-0615/001-001, coordinator of project: Csilla Bartha. The author wishes to thank András Vargha for performing statistical analyses for this research.

\section{Address:}

Anna Borbely

Benczúr utca 33

H-1068 Budapest

Hungary

E-mail: borbely@nytud.hu

\section{References}

Baker, C. (1992) Attitudes and language. Clevedon and Philadelphia: Multilingual Matters.

Bartha, Cs. (2007) "Nyelvváltozat és/vagy nyelvcsere - Hat magyarországi kisebbségi közösség nyelvi attit?djeinek összehasonlîtó elemzése”. In E. Zelliger, ed Nyelv, területiség, társadalom, 95-111. Budapest: Magyar Nyelvtudományi Társaság.

Bartha, Cs. and A. Borbély (2006) "Dimensions of linguistic otherness: prospects of minority language maintenance in Hungary". Language Policy 5, 3, 337-365.

Borbély, A. (2001) Nyelvcsere. Budapest: MTA NyTI Élőnyelvi Osztály. 


\section{Anna Borbely}

Borbély, A. (2005) "Changes in bilingual language choice influenced by real and apparent time: panel study in the process of language shift in a romanian minority community living in Hungary”. In J. Cohen, K. T. McAlister, K. Rolstad, and J. MacSwan, eds. ISB4: Proceedings of the 4th International Symposium on Bilingualism, 328-340. Somerville, MA: Cascadilla Press.

Borbély, A. (2006) "Nyelvválasztási szokások a 21. század elején hat magyarországi kisebbségi közösségben”. Érték és Valóság 7, 85-101. Budapest: Fridrich Ebert Stiftung.

Borbély, A. (2007) “Nyelvi attitádök a magyarországi román és szerb közösségben”. In E. Zelliger, ed. Nyelv, területiség, társadalom, 89-94. Budapest: Magyar Nyelvtudományi Társaság.

Brudner, L. A., and D. R. White (1979) "Language attitudes, behavior and intervening variables”. In W. F. Mackey and J. Ornstein, (eds. Sociolinguistic studies in language contact: methods and cases, 51-68. The Hague, Paris, and New York: Mouton Publishers.

Erb, M. (2007) “Nyelvi attitüdök a tarjáni német közösségben”. In E. Zelliger, ed. Nyelv, területiség, társadalom, 61-69. Budapest: Magyar Nyelvtudományi Társaság.

Fishman, J. A. (1968) "Sociolinguistic perspective on the study of bilingualism". Linguistics 39, 21-49.

Gal, S. (1979) Language shift: social determinants of linguistic change in bilingual Austria. New York: Academic Press.

Kontra, M. (1997) “Hungary”. In H. Goebl, P. H. Nelde, Z. Stary, and W. Wölck, eds. Kontaktlinguistik/Contact Linguistics/Linguistique de contact, 2. Halbband/Volume 2/ Tome 2, 1708-1723. Berlin/New York: Walter de Gruyter.

Lambert, W. W. and W. E. Lambert (1973) Social psychology. 2nd ed. Englewood Cliffs, N.J.: Prentice Hall.

Lawson, S. and Sachdev, I. (2000) "Codeswitching in Tunisia: Attitudinal and behavioural dimensions". Journal of Pragmatics 32, 1343-1361.

Lindner, A. and Z. Horváth (2007) "Kunczéné Fellegi Katalin lovagkereszttel kitüntetett matematikatanár”. HVG XXIX, 36, 114.

Pálmainé Orsós, A. (2007) “Nyelvi attitüdök a magyarországi beás közösségben”. In E. Zelliger, ed. Nyelv, területiség, társadalom, 79-88. Budapest: Magyar Nyelvtudományi Társaság.

Uhrin, E. (2007) A magyarországi szlovákok nyelvi attitüdjei. In E. Zelliger, ed. Nyelv, területiség, társadalom, 70-78). Budapest: Magyar Nyelvtudományi Társaság.

Vargha, A. (2007) Matematikai statisztika pszichológiai, nyelvészeti és biológiai alkalmazásokkal. Budapest: Pólya Kiadó. 
Woolard, K. A. and Gahng, T.-J. (1990) "Changing language policies and attitudes in Autonomous Catalonia". Language in Society 19, 311-330.

Kokkuvõte. Anna Borbely: Keeled ja keelevariandid: võrdlev uurimus nelja vähemuskogukonna keelelistest hoiakutest Ungaris. Uurimuse keskne eesmärk on analüüsida vähemuskeeltesse suhtumise mustrite varieerumist neljas Ungari vähemuskogukonnas: Saksa, Slovaki, Serbia ja Rumeenia. Analüüs on osa uurimistööst, mis keskendub sellele, kuidas koguda informatsiooni keelevahetusprotsesside kohta Ungari autohtoonsete vähemusrahvuste hulgas. Uurimuse tulemustest nähtub, et need kogukonnad, kus keelevahetus on kaugemale arenenud, suhtuvad oma vähemuskeeltesse vähem positiivselt kui need, kelle keelevahetus ei ole nii kaugele arenenud. Ungari vähemuskeelte kõnelejate suhtumine vähemuskeele variantidesse (murre vs. standardkeel) on n-ö keelevahetuse sümptomiteks.

Märksõnad: keelevahetus, keelehoiakud, murre $v s$. standardkeel, võrdlev uurimistöö 
